\title{
Comparison of atmospheric aerosol optical depths measured with different sun photometers in three regions of Spitsbergen Archipelago
}

Dmitry M. Kabanov, Sergey M. Sakerin, Ivan A. Kruglinsky, Christoph Ritter, Piotr S. Sobolewski, et al.

Dmitry M. Kabanov, Sergey M. Sakerin, Ivan A. Kruglinsky, Christoph Ritter, Piotr S. Sobolewski, Tymon Zielinski, "Comparison of atmospheric aerosol optical depths measured with different sun photometers in three regions of Spitsbergen Archipelago," Proc. SPIE 10833, 24th International Symposium on Atmospheric and Ocean Optics: Atmospheric Physics, 1083342 (13

December 2018); doi: 10.1117/12.2503949

Event: XXIV International Symposium, Atmospheric and Ocean Optics, Atmospheric Physics, 2018, Tomsk, Russian Federation 


\title{
Comparison of atmospheric aerosol optical depths measured with different sun photometers in three regions of Spitsbergen Archipelago
}

\author{
Dmitry M. Kabanov ${ }^{\mathrm{a}}$, Sergey M. Sakerin ${ }^{\mathrm{a}}$, Ivan A. Kruglinsky ${ }^{\mathrm{b}}$, Cristoph Ritter ${ }^{\mathrm{c}}$, \\ Piotr S. Sobolewski ${ }^{\text {, Tymon Zielinski }}{ }^{\mathrm{e}}$ \\ ${ }^{a}$ V.E. Zuev Institute of Atmospheric Optics, Siberian Branch, Russian Academy of Sciences, \\ Academician Zuev Square 1, Tomsk, Russia, 634021; ${ }^{\mathrm{b}}$ Tomsk State University, Lenin Ave. 36, \\ Tomsk, Russia, 634050; 'Alfred Wegener Institute for Polar and Marine Research, Potsdam, \\ Germany; ${ }^{\mathrm{d}}$ Institute of Geophysics, Polish Academy of Sciences, Warsaw, Poland; ${ }^{\text {Institute of }}$ \\ Oceanology, Polish Academy of Sciences, Sopot, Poland
}

\begin{abstract}
Results of multiyear (2011-2017) aerosol monitoring were used to compare the spectral aerosol optical depths (AOD) of the atmosphere, measured with different sun photometers at three Arctic stations on Spitsbergen Archipelago: Hornsund, Barentsburg, Ny-Ålesund. In addition to agreement of data in three regions, we also found that AOD in Barentsburg slightly (comparable to error) exceeds those from other stations located 110-120 km away. The AOD discrepancy is more pronounced in the shortwave part of the spectrum, indicating more abundant fine-mode aerosol in Barentsburg.
\end{abstract}

Keywords: aerosol optical depth, Spitsbergen

\section{INTRODUCTION}

Method of sun photometry of the atmosphere is widely used in aerosol studies at network stations and, in particular, in hard-to-reach and less studied regions of Arctic ${ }^{1-5}$. Photometric observations of direct solar radiation in different parts of spectrum make it possible to determine the aerosol optical depth (AOD), as well as atmospheric column contents of water vapor and ozone. Based on spectral measurements of atmospheric AOD, the methods of solution of inverse problems are used to retrieve additionally the aerosol microstructure parameters.

The Spitsbergen Archipelago is one of the most high-latitude regions, where multiyear measurements of spectral AOD of the atmosphere have been conducted at three scientific stations (in the order of decreasing latitude): 1) Ny-Ålesund (AWI, Germany); 2) Barentsburg (AARI and IAO SB RAS, Russia); 3) Hornsund (IGF and IO PAN, Poland). Distances from Barentsburg to Ny-Ålesund and Hornsund stations are 110 and $120 \mathrm{~km}$ respectively. Mutual positions of these stations are shown in Figure 1. The main characteristics of the photometers are presented in Table 1.

Atmospheric AOD has been most long (from April 2000) observed in scientific settlement Ny-Ålesund $\left(78^{\circ} 54^{\prime} \mathrm{N}\right.$, $11^{\circ} 53^{\prime} \mathrm{E}$ ) with the use of the sun photometers SP1A and SP2 $\mathrm{H}^{6}$. Analogous measurements were initiated in 2005 in settlement Hornsund $\left(77^{\circ} 00^{\prime} \mathrm{N}, 15^{\circ} 34^{\prime} \mathrm{E}\right)$ with the help of CE 318 Sun-Sky radiometer (AERONET) ${ }^{7}$ and portable sun photometer Microtops II $^{8}$. Monitoring of optical and microphysical characteristics of aerosol had been initiated in 2011 at Russian scientific center in Barentsburg settlement ${ }^{9}\left(78^{\circ} 04^{\prime} \mathrm{N}, 14^{\circ} 13^{\prime} \mathrm{E}\right)$. AOD was first measured with portable sun photometer SPM ${ }^{10}$, which in 2015 was changed to automated photometer SP-9 with Sun tracking system.

Measurements with different types of sun photometers and methods of calculating the atmospheric AOD can be intercompared in view of the relatively small distance between the scientific stations. Data comparison is very important for a more reliable aerosol monitoring. In addition, the observations in neighboring regions make it possible to estimate the spatial inhomogeneities in AOD, caused by natural factors, or a possible anthropogenic influence of the bigger Barentsburg settlement.

*dkab@iao.ru; phone+7 (3822) 492-848; fax +7 (3822) 492-086; contact@iao.ru

24th International Symposium on Atmospheric and Ocean Optics: Atmospheric Physics, edited by Gennadii G. Matvienko, Oleg A. Romanovskii, Proc. of SPIE Vol. 10833, 1083342

(C) 2018 SPIE $\cdot$ CCC code: $0277-786 X / 18 / \$ 18 \cdot$ doi: $10.1117 / 12.2503949$ 


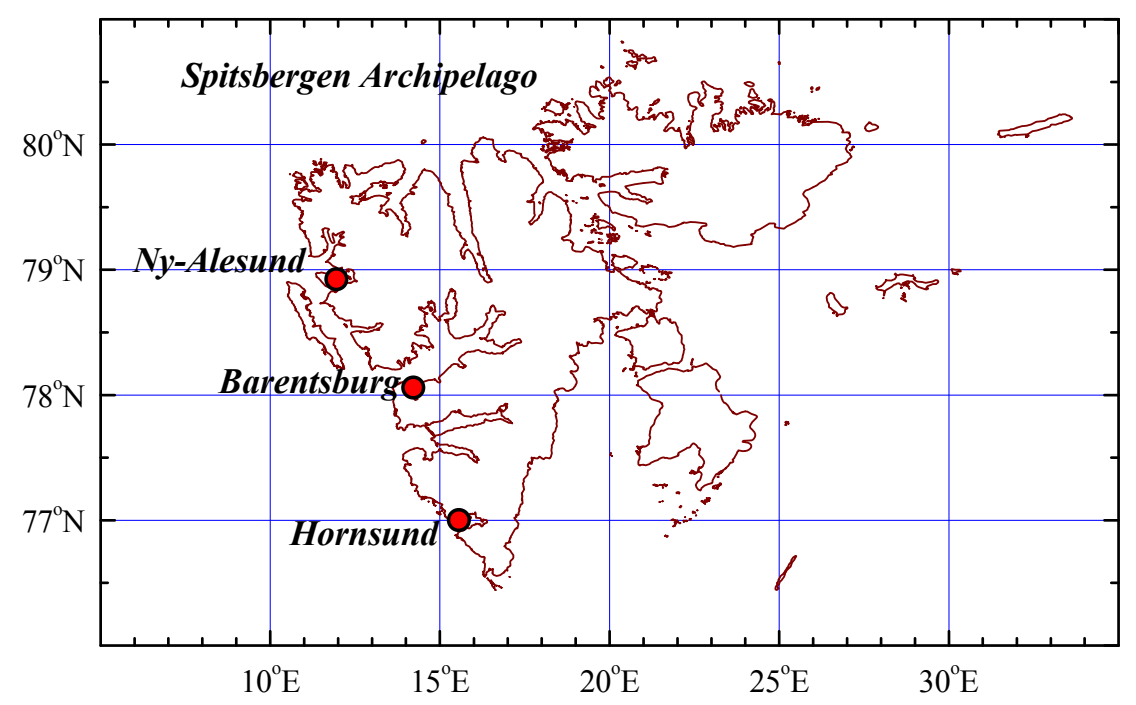

Fig. 1. Location of the AOD observation points in the Spitsbergen archipelago

Table 1. Characteristics of Sun-photometers at three scientific stations of the Spitsbergen archipelago

\begin{tabular}{|c|c|c|}
\hline Scientific stations (groups) & Sun-photometers & $\begin{array}{l}\text { Range of spectrum // number of } \\
\text { spectral channels of AOD }\end{array}$ \\
\hline Ny-Alesund (AWI, Germany) & $\begin{array}{l}\text { SP1A } \\
\text { SP2H }\end{array}$ & $\begin{array}{l}0.37-1.06 \mu \mathrm{m} / / 13 \\
0.37-1.05 \mu \mathrm{m} / / 12\end{array}$ \\
\hline Barentsburg (AARI and IOA SB RAS, Russia) & $\begin{array}{l}\text { SPM } \\
\text { SP-9 }\end{array}$ & $\begin{array}{l}0.34-2.14 \mu \mathrm{m} / / 11 \\
0.34-2.14 \mu \mathrm{m} / / 13\end{array}$ \\
\hline $\begin{array}{r}\text { Hornsund (GSFC/NASA and IGF PAN, Poland) } \\
\text { (IO PAN, Poland) }\end{array}$ & $\begin{array}{l}\text { Cimel CE } 318 \\
\text { Microtops II } \\
\end{array}$ & $\begin{array}{l}0.34-1.05 \mu \mathrm{m} / / 7 \\
0.34-0.87 \mu \mathrm{m} / / 4 \\
\end{array}$ \\
\hline
\end{tabular}

Authors of work ${ }^{5}$ carefully overviewed the studies of aerosol characteristics in different regions of Arctic in the recent period (2000-2012). AOD measurements at two stations on Spitsbergen (Ny-Ålesund and Hornsund) in 2010-2015 were analyzed in more detail in work ${ }^{11}$. Comparison of data of independent (with respect to periods of) measurements at these stations showed that AOD values are much larger at Hornsund. The average difference in the annual and seasonal AOD values at the wavelength $0.55 \mu \mathrm{m}$ is $0.01-0.02$. The discrepancies in the data are mainly observed in periods of Arctic haze and outflows of smokes from forest fires that are differently manifested in the two Spitsbergen regions. When situations with elevated atmospheric turbidities are excluded from consideration, the AOD difference becomes insignificant.

In the present work, we compare AOD in three regions of Spitsbergen: Barentsburg against Ny-Ålesund and Hornsund. It is important to note that our results cannot be considered as an intercalibration of photometers, when measurements are performed at a single location at the same time; correspondingly, the differences between the data depend only on instrumental-methodic errors of measurement facilities. In the given case, an additional (and, possibly, main) factor of AOD differences is that weather conditions differ in each of the regions: local weather conditions, intensity of anthropogenic aerosol sources, type and state of the underlying surface, relief, etc.

\section{RESULTS}

In contrast to ${ }^{11}$, the AOD differences in the neighboring regions were estimated by comparing the data of quasisynchronous (nearly time coincident) measurements with two photometers: "Barentsburg - Hornsund" and "Barentsburg - Ny-Ålesund". The set of hourly average (integer value of hour $\pm 30 \mathrm{~min}$ ) AOD values, measured in Barentsburg with SPM or SP-9 (henceforth SPM) photometers was taken as a basis. We analogously prepared the sets of hourly average AOD values, measured at Hornsund or $\mathrm{Ny}$-Ålesund. Then, the datasets from photometers intercompared were "tailored", if AOD measurements differed by no more than $\Delta \mathrm{t}=1 \mathrm{~h}$ in time. (Comparison was also done for other $\Delta \mathrm{t}$, which however altered little the ultimate result). 
From comparison of joint data it can be seen (Figure 2) that the largest differences are observed for large AOD values during outflows of forest fire smokes and other extreme turbidities. These rare events differ by large spatial AOD inhomogeneity and introduce considerable distortions in comparison results. Therefore, in ultimate form the data were intercompared for AOD $(0.5 \mu \mathrm{m})<0.2$. Scatter diagrams of the joint AOD values for this case are presented in Figure 3: (a) "Barentsburg - Hornsund" and (b) "Barentsburg - Ny-Ålesund". Equations of linear regression between AOD values in the neighboring regions have the form: (a) $\mathrm{Y}=0.028+0.532 \cdot \mathrm{X}$ (dotted line), $\mathrm{Y}=0.841 \mathrm{X}$ (solid line); (b) $\mathrm{Y}=0.015$ $+0.637 \cdot \mathrm{X}$ (dotted line), and $\mathrm{Y}=0.810 \mathrm{X}$ (solid line).
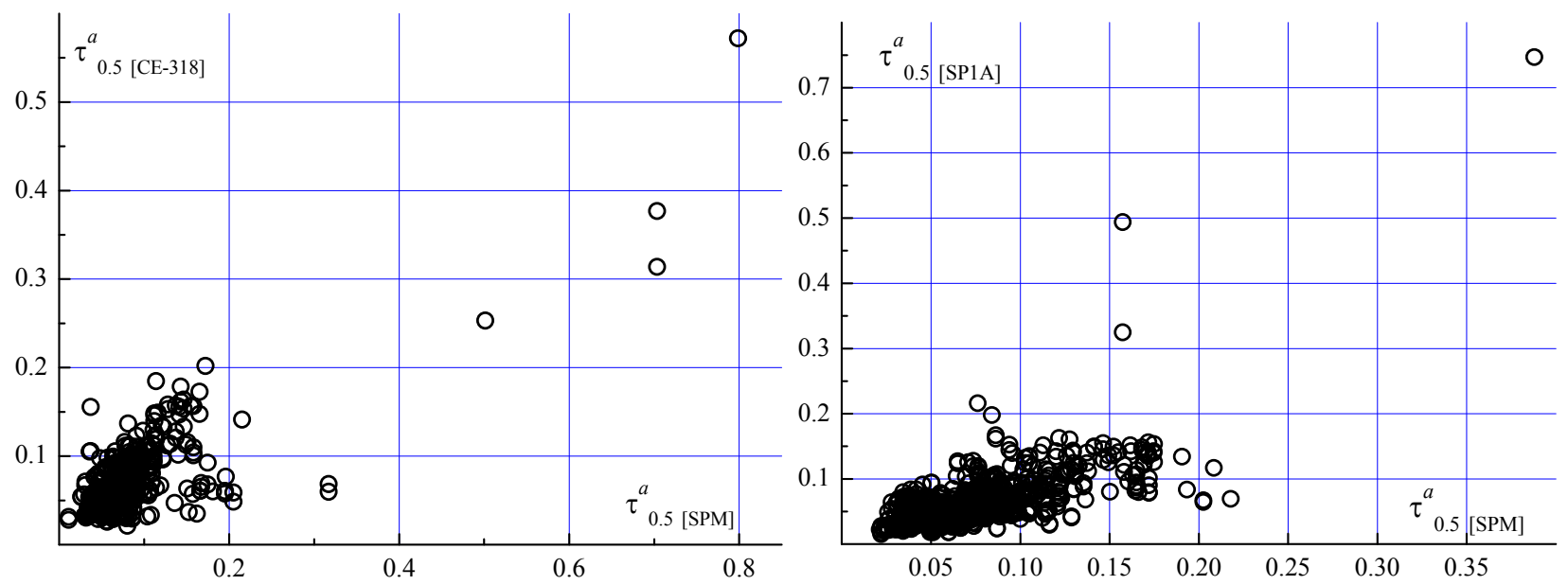

Fig. 2. Diagram of scattering of joint values of AOD $(0.5 \mu \mathrm{m})$ «Barentsburg - Hornsund» (a) and «Barentsburg Ny-Alesund» (b)
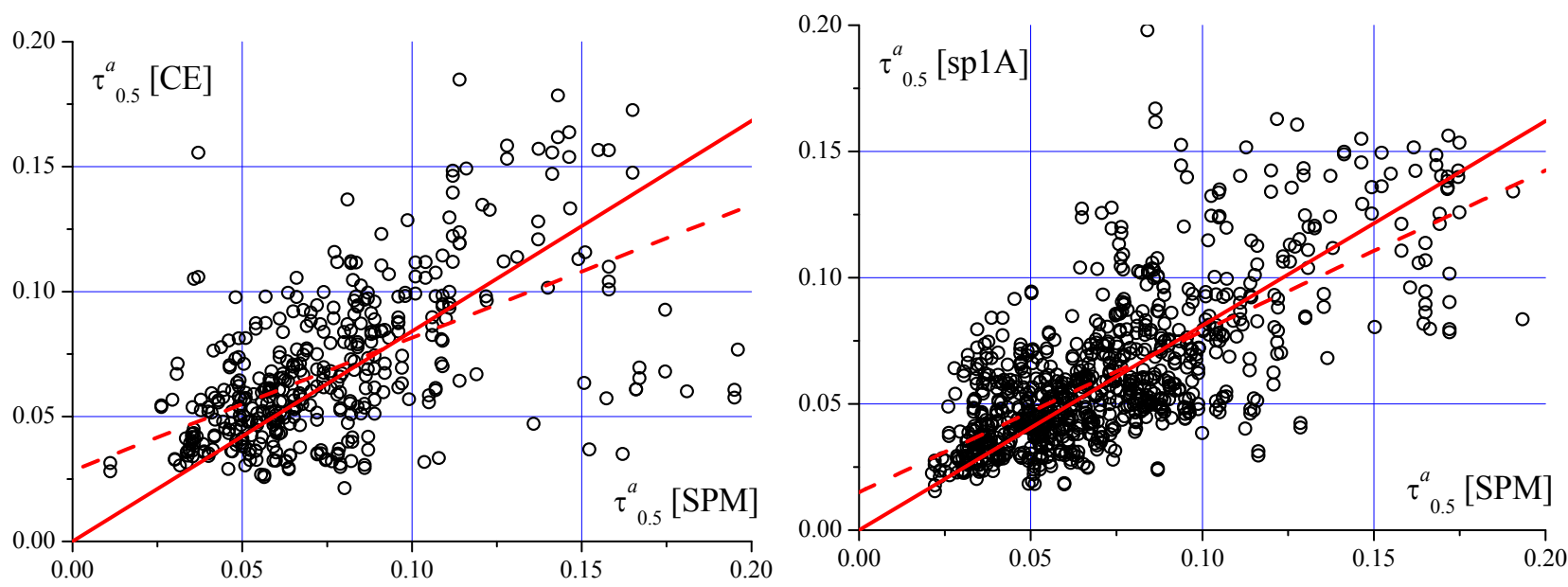

Fig. 3. Diagram of scattering of joint values of AOD $(0.5 \mu \mathrm{m})$ «Barentsburg - Hornsund» (a) and «Barentsburg Ny-Alesund» (b) for AOD $<0.2$

Comparative analysis of AOD characteristics in the neighboring regions (Table 2) and frequency histograms of differences (Figure 4) showed a minor, but statistically significant excess of AOD at Barentsburg over that at NyÅlesund and Horsund stations. In both cases, the difference $(\Delta)$ is maximal in shortwave part of the spectrum. Therefore, the content of the fine-mode aerosol is a little larger in the bigger Barentsburg settlement than in the regions of other scientific stations. The small (10-20\%) AOD difference, comparable to the error, indicates that the studied characteristics are close in value at the three stations.

In addition to anthropogenic factor, the diverging AOD at Barentsburg could be due to different meteorological conditions and, primarily, due to different wind characteristics in the neighboring regions. To clarify the matters, we analyzed the AOD differences ("Barentsburg - Ny-Ålesund" and "Barentsburg - Hornsund") as functions of wind speed 
and direction in each region. In the calculations we used meteorological parameters available at "Reliable Prognosis" website (https://rp5.ru/Weather_in_the_world).

Our analysis revealed no dependence of AOD differences in neighboring regions on wind speed. The "Barentsburg Hornsund" AOD comparison showed quite definitely the dependence on wind direction (Figure 5a): larger values $(\Delta=$ 0.05-0.06) are observed for wind directions from the southern sector $\left(150^{\circ}-200^{\circ}\right)$. In the joint "Barentsburg $-\mathrm{Ny}-$ Ålesund" data no explicitly manifested interrelation between $\Delta$ and wind direction is observed (Figure $5 b$ ).

Table 2. Statistics of comparison results: mean ( $\pm \mathrm{SD})$ values, mean difference $\Delta=\tau^{a}(\mathrm{SPM})-\tau^{a}$ (SP1A or CE 318$)$, correlation coefficients $\mathrm{R}, \mathrm{N}$ - data amount

\begin{tabular}{|l|c|c|c|c|c|c|c|c|}
\hline & \multicolumn{2}{|c|}{ «arentsburg-Ny-Alesund» $(\mathrm{N}=887)$} & \multicolumn{3}{c|}{ «Barentsburg - Hornsund» $(\mathrm{N}=426)$} \\
\hline & SPM & SP1A & $\mathrm{R}$ & $\Delta$ & SPM & CE 318 & $\mathrm{R}$ & $\Delta$ \\
\hline$\tau^{a}(0.38)$ & $0.117 \pm 0.076$ & $0.093 \pm 0.093$ & 0.83 & $0.024 \pm 0.052$ & $0.126 \pm 0.098$ & $0.102 \pm 0.074$ & 0.77 & $0.024 \pm 0.062$ \\
\hline$\tau^{a}(0.5)$ & $0.077 \pm 0.058$ & $0.068 \pm 0.078$ & 0.89 & $0.009 \pm 0.038$ & $0.086 \pm 0.077$ & $0.074 \pm 0.059$ & 0.81 & $0.012 \pm 0.046$ \\
\hline$\tau^{a}(0.87)$ & $0.037 \pm 0.027$ & $0.032 \pm 0.037$ & 0.83 & $0.005 \pm 0.021$ & $0.043 \pm 0.035$ & $0.039 \pm 0.028$ & 0.71 & $0.004 \pm 0.025$ \\
\hline$\alpha$ & $1.38 \pm 0.36$ & $1.39 \pm 0.42$ & 0.10 & - & $1.28 \pm 0.37$ & $1.27 \pm 0.37$ & 0.16 & - \\
\hline$\beta$ & $0.043 \pm 0.027$ & $0.026 \pm 0.032$ & 0.63 & - & $0.042 \pm 0.038$ & $0.032 \pm 0.024$ & 0.54 & - \\
\hline
\end{tabular}
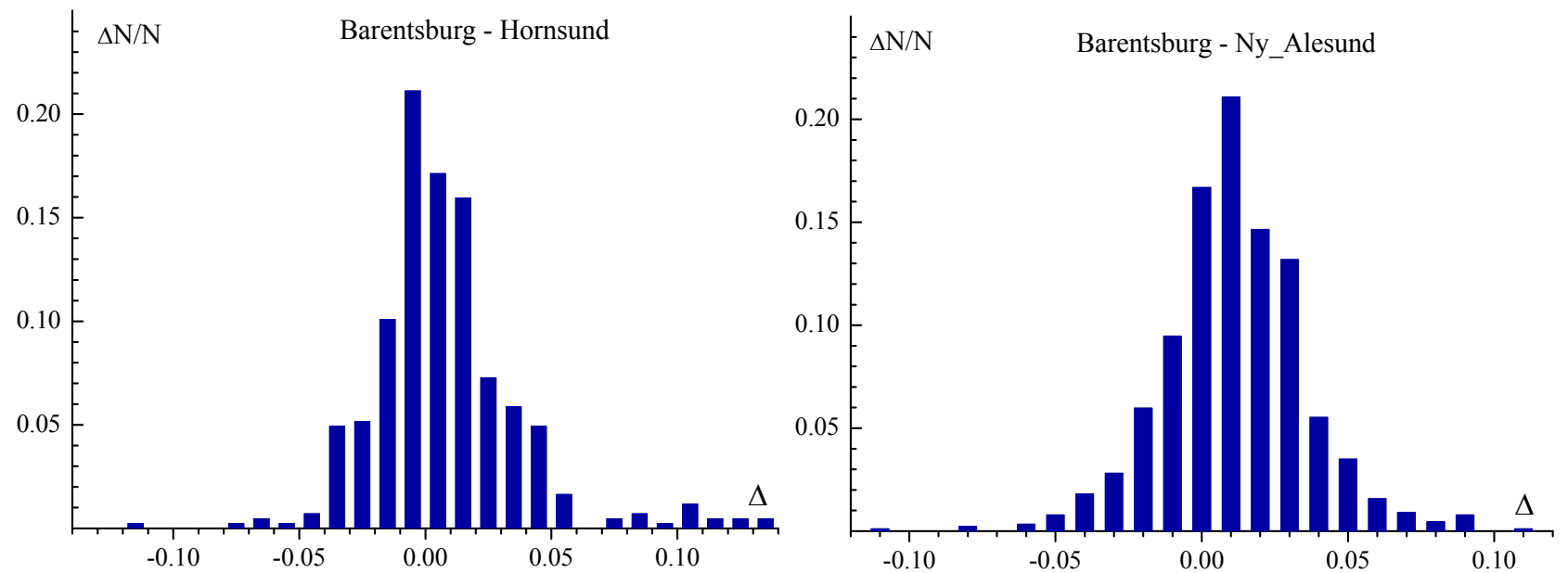

Fig. 4. Frequency histograms of the differences in neighboring areas of Spitsbergen
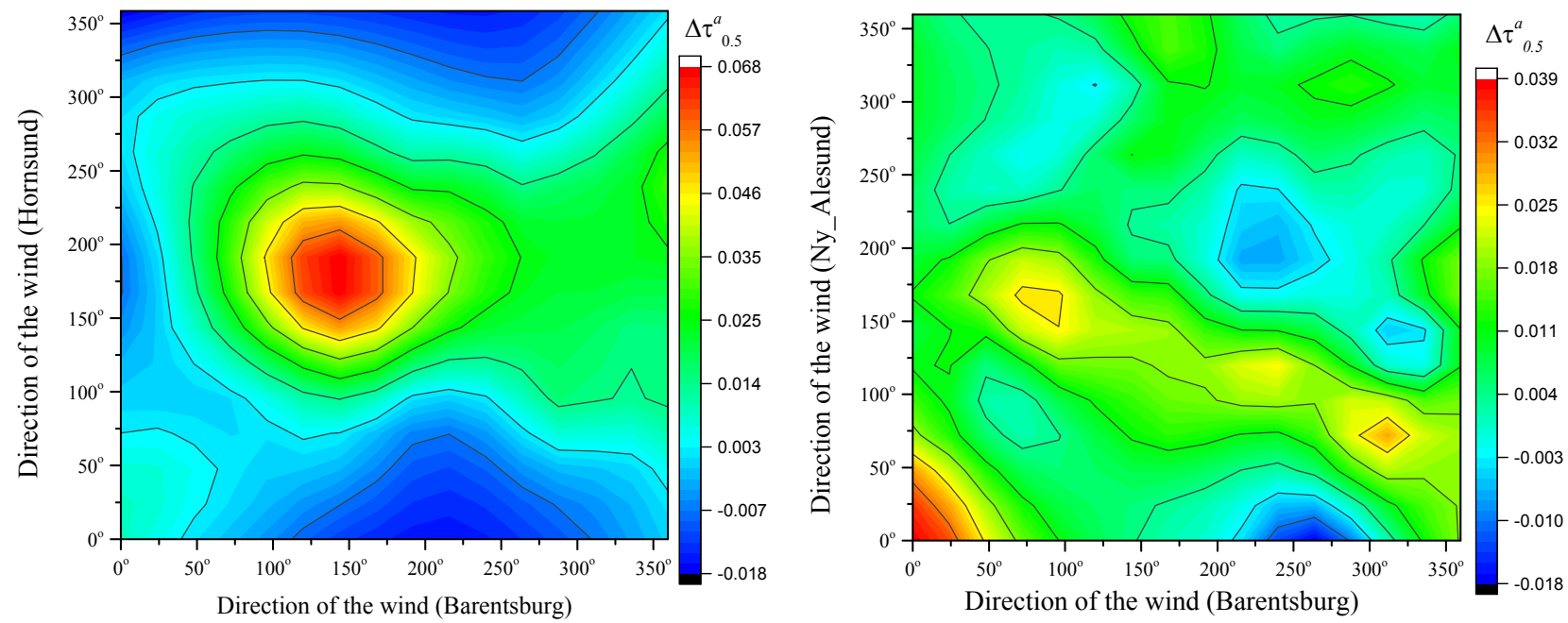

Fig. 5. Average distribution of AOD differences ("Barentsburg - Hornsund" and "Barentsburg - Ny-Ålesund") as a function of wind direction at each site 


\section{CONCLUSIONS}

We compared the multiyear (2011-2017) measurements of spectral AOD of the atmosphere at Arctic stations Hornsund, Barentsburg, and Ny-Ålesund. Comparison of data of quasi-synchronous measurements showed a minor (comparable to error) excess of AOD at Barentsburg over that at neighboring stations. The AOD difference is more pronounced in shortwave part of the spectrum, indicating larger content of fine-mode aerosol at Barentsburg. Analysis of joint "Barentsburg - Hornsund" AOD values revealed larger AOD differences for wind directions from the southern sector.

\section{ACKNOWLEDGEMENTS}

The authors thank their colleagues who participated in preparation of instrumentation and in measurements, i.e., D.G. Chernov, A.V. Gubin, K.E. Lubo-Lesnichenko, A.N. Prakhov, A.P. Rostov, O.R. Sidorova, S.A. Turchinovich, and Yu.S. Turchinovich.

These studies were supported by the Complex Program II.1 of Basic Research, Siberian Branch, Russian Academy of Sciences (through projects nos. 0368-2018-0014).

\section{REFERENCES}

[1] Delene, D.J., and Ogren J.A., "Variability of aerosol optical properties at four North American surface monitoring sites," J. Atmos. Sci., 59, 1135-1150 (2002).

[2] Stone, R.S., "Monitoring aerosol optical depth at Barrow, Alaska, and South Pole; historical overview, recent results and future goals," SIF Conf. Proc. 80, 123-144 (2002).

[3] Stohl A., Andrews E., Burkhart J.F., Forster C., Herber A., Hoch S.W., Kowal D., Lunder C., Mefford T., Ogren J.A., Sharma S., Spichtinger N., Stebel K., Stone R., Ström J., Tørseth K., Wehrli C., Yttri K.E., "PanArctic enhancements of light absorbing aerosol concentrations due to North American boreal forest fires during summer 2004," J. Geophys. Res. 111(D22214). http://dx.doi.org/10.1029/2006JD007216. (2006).

[4] Stone R.S., Anderson G.P., Shettle E.P., Andrews E., Loukachine K., Dutton E.G., Schaaf C., Roman III M.O., "Radiative impact of boreal smoke in the Arctic: Observed and modeled," J. Geophys. Res. 113(D14S16). http://dx.doi.org/10.1029/2007JD009657. (2008).

[5] Tomasi C., Kokhanovsky A.A., Lupi A., Ritter C., Smirnov A., Mazzola M, Stone R.S., Lanconelli C., Vitale V., Holben B.N., Nyeki S., Wehrli C., Altonen V., Leeuw G.de, Rodriguez E., Herber A.B., Stebel K., Stohl A., O’Neill N.T., Radionov V.F., Zielinski T., Petelski T., Sakerin S.M., Kabanov D.M., Xue Y., Mei L., Istomina L., Wagener R., McArthur B., Sobolewski P.S., Butler J., Kivi R., Courcoux Y., Larouche P., Broccardo S., and Piketh S.J., "Aerosol remote sensing in polar regions," Earth-Science Reviews. 140. 108-157 (2015).

[6] Herber A., Thomason L.W., Gernandt H., Leiterer U., Nagel D., Schulz K., Kaptu J., Albrecht T., Notholt J., "Continuous day and night aerosol optical depth observations in the Arctic between 1991 and 1999," J. Geophys. Res. 107(D10), 4097, doi:10.1029/2001JD000536 (2002).

[7] Holben B.N., Eck T.F., Slutsker I., Tanre D., Buis J.P., Setzer A., Vermote E., Reagan J.A., Kaufman Y.J., Nakadjima T., Lavenu F., Jankowiak I., and Smirnov A., "AERONET - A federated instrument network and data archive for aerosol characterization," Rem. Sens. Env. 66(1), 1-16 (1998).

[8] Morys M., Mims III F.M., Hagerup S., Anderson S.E., Baker A., Kia J., and Walkup T., "Design, calibration, and performance of MICROTOPS II handheld ozone monitor and Sun photometer," J. Geophys. Res. 106. $14,573-14,582(2001)$.

[9] Savatyugin L.M. and Solov'yanova I.Yu., "Russian scientific center at the Spitsbergen Archipelago," Ross. Polyarn. Issled., 3(1), 13-15 (2011). [in Russian]

[10] Sakerin S.M., Kabanov D.M., Rostov A.P., Turchinovich S.A., and Knyazev V.V., "Sun photometers for measuring spectral air transparency in stationary and mobile conditions," Atmos. Ocean. Opt. 26(4), 352-356 (2013).

[11]Pakszys P., Zielinski T., "Aerosol optical properties over Svalbard: a comparison between Ny-Ålesund and Hornsund," Oceanologia 59, 431-444. http://dx.doi.org/10.1016/j.oceano.2017.05.002. (2017). 